\title{
PERBANDINGAN PEMAHAMAN KONSEP SISWA PADA PEMBELAJARAN IMPULS DAN MOMENTUM MENGGUNAKAN MEDIA ANIMASI 3D DENGAN 2D
}

\author{
Haditya Aprita Lora \\ Feriansyah Sesunan \\ Ismu Wahyudi \\ Pendidikan Fisika, FKIP, Universitas Lampung \\ Email: h.apritalora@gmail.com
}

\begin{abstract}
This research aims to know a better concept comprehension between using $3 D$ animation learning media with $2 D$ on Impuls and Momentum learning and describe the concept comprehension on both treatments. The research method used is quantitative and descriptive. The research data was obtained through multiple choice test with the certainty of response index (CRI) answer sheet. The research design used was Pretest-Posttest Equivalent Group Design with a sample of two experimental classes selected at random. The results using Mann Whitney U-Test showed a significance value of 0.009. This shows that the students' concept comprehension using $3 D$ animation learning media is higher than using $2 D$ animated learning media. The concept comprehension of students who understand the concept of the class using 3D animation media that is $41.99 \%$, while the class that uses $2 D$ animation media is $34.38 \%$. For the misconception level in the classroom that uses 3D animation media that is $41.02 \%$, while the class that uses 2D animation media is $43.95 \%$.
\end{abstract}

Keywords: $3 D$ and $2 D$ animation, concept comprehension, Impulse and Momentum.

\section{PENDAHULUAN}

Pembelajaran sains yang sangat perlu dalam menggunakan media pembelajaran salah satunya adalah bidang ilmu fisika. Fisika merupakan salah satu bagian Ilmu Pengetahuan Alam dari fenomena alam (Yogantari, 2015). Pembelajaran fisika tidak bisa lepas darisuatu kegiatan pengamatan, percobaan, serta penelitian dan kegiatan ilmiah lainnya (Mashuri, et al.,. 2015).

Salah satu materi fisika yang memerlukan kegiatan pengamatan dan percobaan adalah materi Impuls dan Momentum. Berdasarkan hasil 
wawancara dengan salah satu guru mata pelajaran fisika di salah satu SMA Negeri di Kabupaten Pringsewu Provinsi Lampung pengamatan dan percobaan materi Impuls dan Momentum jarang dilakukan. Hal tersebut terjadi karena percobaan membutuhkan ruangan yang cukup luas dan membutuhkan waktu yang relatif lama, sehingga dapat dikatakan jam pelajaran yang diberikan sekolah tidak cukup jika dilakukan percobaan. Permasalahan lain menurut hasil penelitian yang dilakukan oleh Arief, Handayani dan Dwijananti (2012) pada siswa RSBI se-Kota Semarang mengenai kesulitan dalam mempelajari materi fisika disebabkan oleh faktor minat, bakat, motivasi, intelegensi, fasilitas sekolah, guru, sarana atau prasarana pendukung, dan aktivitas.

Percobaan secara langsung dirasa sangat sulit dilakukan, terlalu rumit, tidak tersedia alat dan bahan karena mahal, atau praktikum yang dilakukan dirasa membahayakan bagi praktikan, maka dapat digunakan alternatif media lain untuk menunjang pembelajaran tersebut, salah satunya yakni visualisasi animasi meng- gunakan komputer (Triwibowo, Abdurrahman \& Nyeneng., 2013).

Hasil penelitian sebelumnya dari Sari dan Samawi (2014) yakni penggunaan media animasi sebagai media gambar bergerak meningkatkan hasil belajar siswa. Ketuntasan belajar siswa yang awalnya berada pada kategori cukup meningkat sehingga berada pada kategori baik setelah dilakukan pembelajaran menggunakan media tersebut. Hal tersebut didukung dengan hasil penelitian Rahmattullah (2011) yang juga memperoleh kesimpulan bahwa terdapat peningkatan (gain) hasil belajar siswa pada kelas eksperimen yang menggunakan media pembelajaran animasi lebih baik dari kelas kontrol yang tidak menggunakan media pembelajaran animasi. Penelitian lain yang turut mendukung pendapat tersebut yakni dari hasil penelitian Suyatna, et al. (2017) yakni penggunaan media visual dinamis atau gambar bergerak dapat meningkatkan hasil belajar siswa dibandingkan menggunakan media visual statis atau gambar diam, 


\section{H, A, Lora., F, Sesunan., I, Wahyudi. - Perbandingan Pemahaman Konsep...}

khususnya pada pembelajaran materi Impuls dan Momentum.

Berdasarkan pemaparan hasil penelitian mengenai penggunaan media animasi, dapat kita ketahui bahwa peningkatan tersebut dikarenakan siswa dapat lebih mudah dalam memahami materi. Menurut Aunurrahman (2013: 54) pemahaman konsep dapat diartikan sebagai proses berpikir seseorang untuk mengolah bahan belajar yang diterima sehingga menjadi bermakna. Dapat dikatakan bahwa pemahaman konsep merupakan salah satu proses berpikir yang berkaitan dalam mengartikan sejumlah fakta dengan kemudian mengungkapkan gagasan yang mewakili sejumlah fakta tersebut secara umum.

Salah satu cara untuk mengetahui pemahaman konsep siswa adalah dengan menggunakan metode CRI (Certainty of Response Index) pada saat tes hasil belajar siswa. Seseorang yang mengalami miskonsepsi dapat dibedakan dengan cara membandingkan benar atau tidaknya jawaban dengan tinggi atau rendah CRI yang diberikannya untuk jawaban soal tersebut (Hafizah, Haris \& Eliwatis, 2014). CRI didasarkan pada skala yang diberikan bersamaan dengan jawaban soal. Adapun skala CRI dapat dilihat pada Tabel 1.

Tabel 1. Skala CRI Saleem Hasan

\begin{tabular}{cc}
\hline Skala & Kategori \\
\hline 0 & Benar - benar jawaban menebak (totally guess answer) \\
1 & Agak menebak (almost guess) \\
2 & Tidak yakin (not sure) \\
3 & Yakin (sure) \\
4 & Agak sangat yakin (almost certain) \\
5 & Sangat yakin (certain) \\
\hline
\end{tabular}

(Mustaqim., Zulfiani, \& Herlanti., 2014)

Jawaban benar dengan CRI yang diberikan atas dasar tebakan tinggi artinya seseorang telah saja, jawaban salah dengan CRI memahami konsep, jawaban benar rendah artinya seseorang tidak dengan CRIrendah artinya jawaban memahami konsep, sedangkan 
jawaban salah dengan CRI tinggi, konsepsi seperti yang ditunjukkan artinya seseorang mengalami mis- pada Tabel 2.

Tabel 2. Ketentuan CRI untuk Membedakan Tahu Konsep, Miskonsepsi, dan Tidak Paham Konsep

\begin{tabular}{lll}
\hline Tipe Jawaban & \multicolumn{1}{c}{ CRI Rendah $(\mathbf{\leq 2 , 5})$} & \multicolumn{1}{c}{ CRI Tinggi $(\mathbf{2 , 5})$} \\
\hline Jawaban Benar & $\begin{array}{l}\text { Apabila peserta menjawab benar } \\
\text { dengan CRI rendah maka } \\
\text { dikategorikan melakukan tebakan } \\
\text { (lucky guess) }\end{array}$ & $\begin{array}{l}\text { Apabila peserta menjawab } \\
\text { benar dengan CRI tinggi maka } \\
\text { dikategorikan memiliki } \\
\text { pemahaman konsep yang baik }\end{array}$ \\
Jawaban Salah & $\begin{array}{l}\text { Apabila peserta menjawab salah } \\
\text { dengan CRI rendah maka } \\
\text { dikategorikan memiliki kurang } \\
\text { pengetahuan (lack of knowladge) }\end{array}$ & $\begin{array}{l}\text { Apabila peserta menjawab } \\
\text { salah dengan CRI tinggi maka } \\
\text { dikategorikan mengalami } \\
\text { miskonsepsi }\end{array}$ \\
\hline
\end{tabular}

Ada beberapa jenis media animasi yang dapat digunakan dalam pembelajaran materi Impuls dan Momentum, contohnya adalah animasi 3 dimensi (3D) dan 2 dimensi (2D). Berdasarkan penelitian terdahulu tentang perbandingan penggunaan animasi $2 \mathrm{D}$ dan $3 \mathrm{D}$ dalam pembelajaran yang telah dilakukan oleh Tavanti \& Lind (2001) menyatakan bahwa animasi tiga dimensi yang realistis dapat membantu mengingat serta meningkatkan kemampuan memahami suatu materi lebih baik jika dibandingkan dengan animasi 2D

Penggunaan media animasi 3D dalam pembelajaran di kelas telah dilakukan sebelumnya oleh Mashuri, et al., (2015) menggunkan aplikasi Autodesk Maya di SMA Al-Kautsar Bandar Lampung menunjukkan bahwa persentase keefektifan media interaktif pembelajaran adalah lebih dari $75 \%$ siswa telah tuntas kriteria ketuntasan minimum (KKM). Penilitan terdahulu oleh Riasti, et al., (2016) tentang penggunaan media animasi 2D dengan aplikasi Microsoft Power Point di SMA Negeri 1 Purbolinggo dengan perolehan hasil belajar siswa $79 \%$ telah lulus dari KKM.

Berdasarkan pernyataan bahwa media interaktif animasi baik 3D maupun 2D memiliki keefektifan dalam peningkatan hasil belajar siswa, maka peneliti melakuan 
penelitian ini dengan tujuan (1)

Mengetahui pemahaman konsep siswa yang lebih baik antara menggunakan media pembelajaran animasi 3D dengan 2D pada materi Impuls dan Momentum, dan (2) Mendeskripsikan pemahaman konsep siswa dengan menggunakan media pembelajaran animasi 3D dan 2D pada materi Impuls dan Momentum.

\section{METODE}

Penelitian ini menggunakan pendekatan kuantitatif dan deskriptif.
Penelitian dilaksanakan pada semester genap tahun pelajaran 2017/2018 di salah satu SMA Negeri di Kabupaten Pringsewu Provinsi Lampung.

Subjek penelitian ini adalah siswa kelas X. Populasi berjumlah 170 siswa. Kemudian dipilih sampel secara acak sebanyak dua kelas atau berjumlah 64 siswa.

Desain penelitian yang digunakan Pretest Posttest Equivalent Group Design, dapat dilihat pada Tabel 3.

Tabel 3. Desain Penelitian One Group Pretest-Posttest Design

\begin{tabular}{cccc}
\hline Kelompok & Pretest & Perlakuan & Posttest \\
\hline $\mathrm{R} 1$ & $\mathrm{O} 1$ & $\mathrm{X} 1$ & $\mathrm{O} 2$ \\
$\mathrm{R} 2$ & $\mathrm{O} 3$ & $\mathrm{X}_{2}$ & $\mathrm{O} 4$ \\
\hline
\end{tabular}

Desain penelitian ini menggunakan dua kelas eksperimen. Pretest diberikan sebelum pembelajaran, dan posttest diberikan setelah pembelajaran. Kelas eksperimen 1 (R1) diberi perlakuan menggunakan media pembelajaran animasi 3D (X1) dan kelas eksperimen 2 (R2) diberi perlakuan menggunakan media pembelajaran animasi 2D (X2).
Pengumpulan data dilakukan dengan tes hasil belajar baik pretest maupun posttest, menggunakan instrumen soal sebanyak 10 butir soal pilihan jamak yang telah diuji validitas dan reliabilitasnya. Setiap butir soal terdapat skala CRI yang ditujukan untuk menganalisis pemahaman konsep siswa.

Analisis data terdiri dari analisis statistik inferensial dan analisis 
deskriptif. Analisis statistik

inferensial digunakan untuk menguji hipotesis apakah diteima atau ditolak. Analisis ini dimulai dengan menguji $\mathrm{N}$-gain perolehan pretest dan posttest siswa, dilanjutkan dengan uji normalitas, uji homogenitas, dan uji beda teknik Mann Whitney U-Test. Hipotesis dalam penelitian ini adalah $\left(\mathrm{H}_{0}\right)$ pemahaman konsep siswa menggunakan media animasi 3D lebih rendah dari atau sama dengan menggunakan media animasi 2D pada materi Impuls dan Momentum,
(H1) pemahaman konsep siswa menggunakan media animasi 3D lebih tinggi dari menggunakan media animasi 2D pada materi Impuls dan Momentum. Pedomannya adalah H1 diterima jika nilai signifikansi $\leq 0,05$ dan $\mathrm{H}_{0}$ diterima jika nilai signifikansi > 0,05.

\section{Kemudian dilakukan Analisis} statistik deskriptif untuk mendeskripsikan persentase pemahaman konsep siswa dari tes hasil belajar tersebut dengan kriteria seperti pada Tabel 4.

Tabel 4. Kriteria penilaian persentase

\begin{tabular}{cc}
\hline Kriteria & Persentase $\mathbf{( \% )}$ \\
\hline Sangat tinggi & $81-100$ \\
Tinggi & $61-80,99$ \\
Sedang & $41-60,99$ \\
Rendah & $21-40,99$ \\
Sangat rendah & $0-20,99$ \\
\hline
\end{tabular}

\section{HASIL DAN PEMBAHASAN}

Bedasarkan tes hasil belajar ratarata seperti diperoleh $\mathrm{N}$-gain seperti ditunjjukkan pada Gambar 1 yang menunjukkan bahwa kelas menggunakan media pembelajaran animasi 3D memperoleh nilai $\mathrm{N}$-gain lebih tinggi dari kelas menggunakan media pembelajaran animasi 2D.
Data perolehan N-gain dilakukan uji normalitas. Hasil uji normalitas pada kelas yang menggunakan media animasi 3D menunjukkan nilai signifikansi 0,002, sedangkan kelas yang menggunakan media animasi $2 \mathrm{D}$ menunjukkan nilai signifikansi 0,200. Berdasarkan acuan nilai signifikansi $>0,050$ menunjukkan data 


\section{H, A, Lora., F, Sesunan., I, Wahyudi. - Perbandingan Pemahaman Konsep...}

berdistribusi normal, maka dapat yang diperoleh tidak semuanya diketahui bahwa data kelas media berdistribusi normal maka pengujian animasi 3D tidak berdisribusi normal hipotesis dilakukan dengan teknik dan data kelas media animasi 2D Mann Whitney U-Test. berdistribusi normal. Oleh karena data

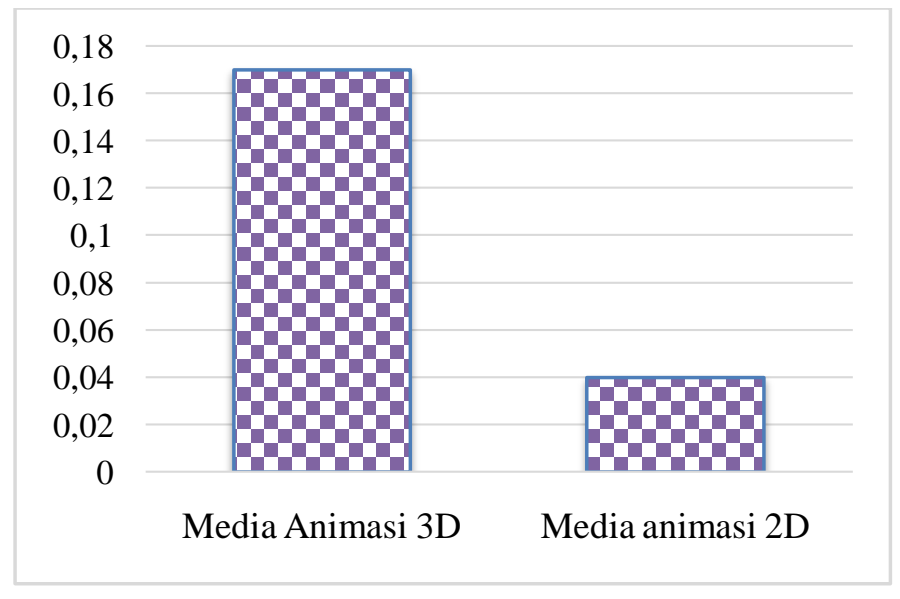

Gambar 2. Rata-rata N-gain

Hasil uji hipotesis yang dapat dilihat pada Tabel 5 yang menunjukkan besar nilai sig. (2tailed) sebesar 0,009. Hal tersebut menunjukkan nilai sig. (2-tailed) kurang dari 0,050 sehingga dapat dikatakan H1 diterima, yakni pemahaman konsep siswa menggunakan media animasi 3D lebih tinggi dari pada menggunakan media animasi 2D pada materi Impuls dan Momentum.

Hasil penelitian ini mendukung hasil penelitian sejenis yang dilakukan Tavanti dan Lind (2001) yakni menggunakan media animasi 3D dapat meningkatkan memori spasial siswa sehingga dapat meningkatkan pemahaman materi siswa lebih baik dari-pada menggunakan medai animasi 2D. Hasil tersebut sejalan dengan hasil penelitian yang dilakukan oleh Nursyamsi et al. (2015) yang menyatakan bahwa media pembelajaran model 3D lebih efektif dalam meningkatkan pemahaman materi dibandingkan dengan media 2D. 
H, A, Lora., F, Sesunan., I, Wahyudi. - Perbandingan Pemahaman Konsep...

Tabel 5. Hasil uji Mann Whitney U-Test

\begin{tabular}{cccc}
\hline Mann-Whitney & Wilcoxon $\boldsymbol{W}$ & $\mathbf{Z}$ & Sig. (2-tailed) \\
\hline 318,5 & 846,5 & $-2,614$ & 0,009 \\
\hline
\end{tabular}

Hasil analisis persentase pemahaman konsep siswa dapat dilihat pada Tabel

6. Berdasarkan data tersebut, dapat dilihat bahwa rata-rata tingkat paham konsep,siswa pada kelas eksperimen 1 (X1) lebih tinggi dari kelas ekspeimen 2 (X2) yakni sebesar 41,99\% (kategori sedang) dengan 34,38\% (kategori rendah). Rata-rata tingkat miskonsepsi pada kelas X1 yakni $41,02 \%$ (kategori sedang) lebih rendah dari kelas X2 yakni 43,95\% (kategori sedang). Berdasarkan hasil analisis pemahaman konsep siswa, penulis juga menemukan miskonsepsi kategori tinggi siswa terdapat pada soal nomor 7, 8, dan 10 yakni sebesar $75 \%, 75 \%$, dan $93,75 \%$.

Tabel 6. Hasil Pemahaman Konsep Siswa

\begin{tabular}{|c|c|c|c|c|c|c|c|c|c|}
\hline \multirow[t]{2}{*}{ Indikator } & \multirow[t]{2}{*}{ No. Soal } & \multicolumn{2}{|c|}{ Paham Konsep } & \multicolumn{2}{|c|}{ Miskonsepsi } & \multicolumn{2}{|c|}{ Menebak } & \multicolumn{2}{|c|}{$\begin{array}{c}\text { Tidak Paham } \\
\text { Konsep }\end{array}$} \\
\hline & & $X_{1}$ & $\mathbf{X}_{2}$ & $X_{1}$ & $\mathbf{X}_{2}$ & $\mathbf{X}_{1}$ & $\mathbf{X}_{2}$ & $X_{1}$ & $\mathbf{X}_{2}$ \\
\hline 1 & 1 & 40,63 & 59,38 & 59,38 & 37,50 & 0,00 & 3,13 & 0,00 & 0,00 \\
\hline 2 & 2 & 15,63 & 12,50 & 43,75 & 34,38 & 3,13 & 12,50 & 37,50 & 40,63 \\
\hline 3 & 3 & 50,00 & 46,88 & 28,13 & 21,88 & 9,38 & 12,50 & 12,50 & 18,75 \\
\hline 4 & 4 & 81,25 & 87,50 & 12,50 & 6,25 & 6,25 & 6,25 & 0,00 & 0,00 \\
\hline \multirow{2}{*}{5} & 5 & 9,38 & 28,13 & 53,15 & 40,63 & 9,38 & 6,25 & 28,13 & 25,00 \\
\hline & 6 & 6,25 & 0,00 & 53,13 & 43,75 & 0,00 & 0,00 & 40,63 & 56,25 \\
\hline 6 & 7 & 31,25 & 0,00 & 56,25 & 75,00 & 3,13 & 0,00 & 9,38 & 25,00 \\
\hline \multirow{2}{*}{7} & 8 & 6,25 & 28,13 & 75,00 & 59,38 & 0,00 & 0,00 & 18,75 & 12,50 \\
\hline & 9 & 81,25 & 68,75 & 12,50 & 21,88 & 0,00 & 3,13 & 6,25 & 6,25 \\
\hline 8 & 10 & 65,63 & 6,25 & 31,25 & 93,75 & 3,13 & 0,00 & 0,00 & 0,00 \\
\hline \multicolumn{2}{|c|}{ Rata - rata } & 41,99 & 34,38 & 41,02 & 43,95 & 3,71 & 4,88 & 13,28 & 16,80 \\
\hline
\end{tabular}




\section{PENUTUP}

\section{Kesimpulan}

Berdasarkan hasil penelitian dan pembahasan yang telah diuraikan, maka dapat disimpulkan bahwa : (1) Pemahaman konsep siswa menggunakan media pembelajaran animasi 3D lebih tinggi dari media pembelajaran animasi 2D pada materi Impuls dan Momentum. (2) Tingkat pemahaman konsep siswa yang memahami konsep pada kelas menggunakan media animasi 3D sebesar 41,99\%, sedangkan kelas yang menggunakan media animasi 2D sebesar 34,38\%. Untuk tingkat miskonsepsi pada kelas yang menggunakan media animasi 3D sebesar 41,02\%, sedangkan kelas yang menggunakan media animasi 2D sebesar $43,95 \%$.

\section{Saran}

Berdasarkan penelitian telah dilakukan, maka penulis menyarankan beberapa hal sebagai berikut: (1) Sebelum melakukan kegiatan pembelajaran, sebaiknya mengecek dan memperbaharui terlebih dahulu aplikasi untuk membuka media animasi baik 3D maupun 2D agar ketika pembelajaran dimulai media animasi dapat dioperasikan dengan lancar. (2) Pembelajaran menggunakan animasi baik 3D maupun 2D akan lebih baik jika membagi siswa ke dalam kelompok kecil secara heterogen seperti dalam satu kelompok terdapat siswa yang memiliki kemampuan lebih dalam verbal, matematis, operasional, dan visual agar pemahaman materi pembelajaran dapat terlaksana secara merata.

\section{DAFTAR PUSTAKA}

Arief, M. K., Handayani, L., \& Dwijananti, P. (2012). Identifikasi Kesulitan Belajar Fisika Pada Siswa RSBI: Studi Kasus Di RSMABI Se Kota Semarang. Unnes Physics Education. 1(2252). 5-10. Retrieved from http://journal.unnes.ac.id/sju/

Aunurrahman. 2013. Belajar dan Pembelajaran. Bandung: Alfabeta.

Hafizah, D., Haris, V., Eliwatis. (2014). Analisis Miskonsepsi Siswa Melalui Tes Multiple Choice Menggunakan Certainty Of Response Index Pada Mata Pelajaran Fisika Man 1 Bukittinggi. Pendidikan MIPA. 1, 100-103. Retrieved from http://download.portalgaruda.org/a rticle.php?article

Mashuri, M., Ertikanto, C. \& Suana, W. (2015). Pengembangan Media Interaktif Menggunakan Autodesk 
H, A, Lora., F, Sesunan., I, Wahyudi. - Perbandingan Pemahaman Konsep...

Maya Untuk Pembelajaran

Momentum-Impuls Berbasis

Inkuiri. Jurnal Pembelajaran

Fisika. 3(5). 11-24. Retrieved

from

www.jurnal.fkip.unila.ac.id/index. phpp/JPF/article/view/9954

Mustaqim, T. A., Zulfiani, \& Herlanti, Y. (2014). Identifikasi Miskonsepsi Siswa Dengan Menggunakan Metode Certainty of Response Index (CRI) Pada Konsep Fotosintesis Dan Respirasi Tumbuhan. EDUSAINS. 6(2). 147152.

Nursyamsi, A., Gunawan, D., \& Aprilia, I. D. 2015. Perbandingan Media Model 3D Dengan Media Chart 2D Terhadap Pemahaman Bangun Ruang Dalam Pembelajaran Matematika Pada Anak Tunarungu di 2 SLB Kota Banjar. Pendidikan Khusus. 2-3.

Rahmattullah, M. (2011). Pengaruh Pemanfaatan Media Pembelajaran Film Animasi Terhadap Hasil Belajar. Edisi Khusus (1 ISSN 1412-565X). 178-186. Retrieved from http:

http://jurnal.upi.edu/file/17Muhammad_Rahmattullah.pdf

Riasti, M. F., Suyatna, A., \& Wahyudi, I. (2016).

Pengembangan Media Inetraktif Model Tutorial Pada Materi Impuls dan Momentum. Jurnal Pembelajaran Fisika. 4(1). 81-91. Retrieved from www.jurnal.fkip.unila.ac.id/index. phpp/JPF/article/view/13549

Sari, N. W., \& Samawi, A. (2014). Pengaruh Penggunaan Media Animasi Terhadap Hasil Belajar Ipa Siswa Slow Learner. Jurnal Penelitian dan Pengembangan
Pendidikan Luar Biasa. 1(2). 140144. (Online) di http://journal.um. ac.id pada 11 November 2017.

Suyatna, A., Anggraini, D., Agustina, D., \& Widyastuti, D. (2017). The role of visual representation in physics learning: dynamic versus static visualization. In Physics Conference Series. pp. 1-7. https://doi.org/10.1088/17426596/909/1/012048.

Tavanti, M., \& Lind, M. (2001). 2D vs 3D, Implications on Spatial Memory. In Proceedings of the IEEE Symposium on Information Visualization 2001 (INFOVIS'01). Vol. 2001. p. 145). Retrieved from https://doi.org/10.1109/INFVIS.20 01.963291 .

Triwibowo, S., Abdurrahman, \& Nyeneng, I. D. P. (2013). Perbandingan Hasil Belajar Kognitif Siswa Menggunakan Media Simulasi Komputer dan Media Realia. Pembelajaran Fisika. 1(7). 77-88. Retrieved from

https://www.jurnal.fkip.unila.ac.id/ index.phpp/JPF/article/view/3371/ 2074

Yogantari, P. (2015). Identifikasi Kesulitan Siswa dalam Pembelajaran Fisika. Seminar Nasional Fisika Dan Pembelajarannya. 7-11. (Online) di www.m-id.123dok.com/ pada 11 November 2017. 